\title{
Information Policy and Hong Kong Schools: A review of the literature and preliminary benchmarking of practice*
}

\author{
James Henri \\ The University of Hong Kong Faculty of Education \\ Sandra Lee \\ The University of Hong Kong Faculty of Education
}

\begin{abstract}
A review of the literature surrounding information policy suggests it is often discussed but it is not clear that it is understood. The policy governing the creation and dissemination of information has existed a long time, but policy development has changed because of the proliferation of resources via the Internet. The concepts of information and policy and the difficulty in defining them are presented. Typical school information policies are discussed in the context of policy development in Hong Kong. The implications of a lack of information policy for schools and school libraries are weighty considering that schools play an important part in the information cycle for students. Reference is made of the author's study to benchmark the existence of information policies in Hong Kong schools.
\end{abstract}

\section{Introduction}

What are the policies guiding the access to, and use of information? This important question affects practically every aspect of life, and therefore, one can assume it is an important question for information professionals. It seems, however, that the development of information policy is regarded as difficult and often takes centre stage in reactive contexts - dramatic tragedy or outrage scandal, or in large-scale international debates-rather than as a normal component of a policy development cycle.

Burger (1993) and Browne (1997) identify three main reasons for the difficulty in understanding information policies. First, there is ongoing debate about what constitutes 'information', how information may be isolated from data and knowledge, and the relationship among information, being informed, and knowing. Second, information policy falls into a complex and broad area of policy, and finally, as a discipline area, information policy is relatively new. Kaiberg and Kristiansson cited in Burger (1993) further state that where there is research and discourse about information policy, there remains a lack of consensus on concepts. As in other contentious areas in the social sciences, nomenclature exists, but the individuals involved have a difficult time agreeing on a theoretical framework underpinning their ideas and giving shared meaning to the nomenclature.

\section{Defining Policy}

What counts as 'policy' is an important benchmark for a literature review about information policy. Levinson and Sutton (2001) describe policy as:

...a kind of normative decision making, and such decision making comprises an integral part of everyday life." On the one hand, public policy is conferred the status of official tool of 
governance. On the other hand, smaller-scale institutions, such as businesses and local schools, may enact their own policies to specify proper procedure and conduct. Our boss may explain the 'company policy,' our principal the 'school policy.' Even individuals have been known to refer to their 'policies'... ( $p .3)$.

In this sense policy might be understood as rules of practice that may or may not be written down.

Debowski (2003) notes that policy is often confused with procedure. Policy is a statement of principle and is usually succinct, general and timeless. Policy is as much a statement about the future as it is about the present. Procedures are detailed, specific and often deal with a particular context and time. Procedure can change even though policy remains constant.

Caldwell and Spinks (1988) provide an analysis of policy and policy making at the school level and emphasis the need for written policy. According to Caldwell and Spinks a policy provides a framework for decision making. It establishes a purpose and guidelines that can be used to clarify the purpose of actions and intentions and upon which alternatives can be chosen. Caldwell and Spinks divide policy into those that are contentious and those that are uncontentious. This division is useful since it provides a direction on policy development. Development of contentious policy will naturally entail a more difficult and lengthy process that would the development of uncontentious policies. Caldwell and Spinks suggest that uncontentious policies can be drafted by a single stakeholder and then shared with wider stakeholders. Contentious policies on the other hand require greater representation of vested interests in the early discussion and drafting processes.

\section{Defining Information}

In any discussion about information policies, (policies about information) it is helpful to be clear on what counts as information. The fact is, however, that in its broadest sense information is everything and everything is information. Bawden, cited in Rowlands (1997) seeks to explain information as a continuum from data to wisdom but this implies a value-added process. The process is a transformative one, adding meaning and context along the way. This approach is not without its critics because of its limitations in a linear delineation. It is entirely possible that wisdom is codified and possibly becomes information and in its raw form, data. (Stenmark, 2002).

Buckland (1991) in one of the most cited articles about information departs from the hierarchical approach and groups approaches into three classes: information as process (the act of informing); information as knowledge (private matter), and information as thing (the public object).

The way that a school understands 'information' is fundamental for almost all other decisions and will certainly dictate the approach a school takes to information policy. Schools that perceive information as an object are likely to focus on information infrastructure such as libraries and computer labs. Such a view often articulates the ratio of information to students - one computer per student, one book per student - and will likely assess learning through quantitative measures such as tests and examinations. Schools that focus on information as a process are likely to focus on evidence that students are becoming informed and equate an information literate teacher as one who has mastered the processes of becoming informed. These schools place emphasis on use 
of information through physically and intellectual access to that information and are likely to assess learning by means of qualitative measures (Henri 2005). Schools that focus on information as knowledge may give greater emphasis to knowledge management and the relationship between learning and knowledge.

\section{Information policy}

Traditionally, authors writing about information policy have often focused on policies governing the control of government information. Braman (1989) for example, argues that information policy at the macro level, at a national government policy level undoubtedly shapes the social, political and economic forces that affect daily life. Braman states:

Because modes of information creation, processing, flows and use are shaped by socioeconomic and political class division and in turn reproduce them, policy-making, too, must take into account qualitative differences in phenomena at different levels of the social structure (1989, p. 233).

In like vein Weingarten (1989) defines information policy as the set of all public laws, regulations and policies that encourage, discourage or regulate the creation, use, storage, and communication of information. Burger observes that there does exist a "disarray of approaches, circular definitions, and quasi-analyses" (1993, p. 90). Rowlands states that "while progress in the field of information policy is being made, it is widely agreed that the subject is presently at an early stage of intellectual maturity, with little consensus or agreement on what precisely the field comprises” (1997, p. 6). Rowlands concludes that while the roots of information policy studies are planted firmly in the library and information science tradition, the research into information policy design lacks the necessary tools and methodology which would enable rigorous analysis. Browne (1997) supports this view and suggests that progress in understanding information policy may be hampered through the lack of a sustained and robust interdisciplinary approach to its analysis and evaluation.

Overman and Cahill (1990) approach the information policy discussion in the context of values, looking at government information and its management in the United States. Their critical appraisal of public policy classifies the following areas into distributive and restrictive sets of values.

- Access and freedom: a pillar of democracy, while acknowledging the paradoxical conflict between freedom, access, and security is: distributive.

- Privacy: Preserving individual rights and attempting to strike some balance between individual needs and public interest is: distributive.

- Openness: Citizens have a right to transparent governments and this is: distributive.

- Usefulness: There are issues related to the regulation of collection and maintenance of public records specifically determining who will decide and control what information is to be considered useful and this is: restrictive.

- Cost and benefit: The bureaucratic side of information policy that seeks to balance commercial interests and public interests. The centre of the debate is who has the right to access what information and this is: restrictive.

- Security and secrecy: Government's authority to make secret certain information for the sake of security is: restrictive. 
- Ownership: This covers the very complex area of intellectual property in an attempt to delineate what is private use and commercial use and what is free or 'fair use': restrictive.

Rowlands (1997) created a matrix to illustrate how information policy seeks to make meaning of the contexts within which value is added to information as public good versus tradable commodity, and access versus secrecy.

Moore (as cited in Rowlands \& Vogel, 1991, p.1) suggests a study of information policy issues can be approached in four broad areas:

- issues concerned with legislation and the regulation of information;

- issues concerned with the role of the information sector within national and international economies;

- local issues that relate to the way information is used within an organization; and

- issues concerned with the contribution that information makes to the effective operation of an increasingly complex social structure.

\section{Information Policy at the Macro Level: Hong Kong}

In March 1998 the Hong Kong Policy Research Institute (PRI) published A Report on a Pilot Study of the Hong Kong Information Infrastructure (Final Report). The study explored the status of information infrastructure in Hong Kong at the end of the century. It was partially funded by the Office of the Telecommunications Authority (OFTA) to support the work of the Information Infrastructure Advisory Committee (IIAC) in Hong Kong. The objectives of this study were:

- to develop meaningful and comparable statistics of the Information Infrastructure across key sectors of Hong Kong;

- measure the status of technology, applications, and user readiness in seven sectors; and

- identify problems, gaps, opportunities, and needs for future Hong Kong information infrastructure development.

The phrase 'Information Infrastructure' has an expansive meaning. PRI defines information infrastructure as the physical and institutional arrangements that create and promote information exchanges. PRI suggests that information infrastructure has four layers, namely, technology, policy, applications, and people. Technology transforms and disseminates information. Policies govern the information flow. Applications deal with human interfaces with technology to realize the information technology benefits. How ready people are at making use of the technologies, policies, and applications determines the overall cost-effectiveness of an information infrastructure. The report surveys the non-policy aspects of the information infrastructure in Hong Kong.

The research involved two phases, a qualitative research phase and a quantitative research phase. It covered seven sectors that included primary and secondary schools, secondary school students, and higher education. The project confirmed that Hong Kong is a highly connected environment in business, universities, schools and homes. Indeed, broadband access to the Internet is commonplace. A key recommendation of the report:

Information infrastructure development cannot be effective without the involvement and participation by the people it serves. PRI recommends that the industries, universities, 
vendors, schools, children, government policy makers, policy researchers, and the public at large all have their important roles to play in the development of information infrastructure in Hong Kong (HKPRI, 1998).

The IIAC completed its work in June 1998. A new IIAC has been established under the auspices of the Communications and Technology Branch (CTB). The CTB has been established within the Commerce and Technology Bureau of the Government of the Hong Kong Special Administrative Region. It provides an extensive website which deals with Information Infrastructure and related issues. This is very helpful for those who are involved in establishing information policies in the Hong Kong and China context.

Information policy is a major program area of the Home Affairs Bureau. It is this bureau that is responsible for the heavily protested and controversial Basic Law. Their stated aims and objectives include the concerns for government accountability. They also aim to protect and enhance freedom of the press, according to the First Report of the HKSAR of the People's Republic of China in the light of the International Covenant on Civil and Political Rights (Home Affairs Bureau, 1999).

Internet traffic is regulated through the Office of the Telecommunications Authority where Internet service providers can apply for licensing. Calls for regulation of ISPs and Internet content were heard in 1995 and a consultation exercise began. The project examined public opinion and information policy developed in other countries to deal with obscene and questionable content (McIntyre, n.d.). Also of note in the policy development arena are the lobbying efforts by the Hong Kong Internet Service Providers Association who have developed views on information policy and presented these to the Hong Kong government.

\section{Information Policy Development Process: Implications for Education and School Libraries}

The best schools have been variously described as 'learning schools' (Lincoln, 1987), 'learning communities' (Cooper \& Boyd, 1995), 'information literate school communities' (Henri 1995, 1999), 'schools that learn' (Senge et al, 2000), and 'knowledge producing schools’ (Bigum, 2004). While these models of school have their peculiarities they share certain key principles of practice. One of the common features is an emphasis on knowledge building driven by a clear vision of what makes a good learner and a good 'apprentice adult' (Henri 2005). It stands to reason if information is the oxygen of learning that the development and articulation of information policies are likely to be a core issue for these schools.

Certainly schools are organizations to which information is central to their core business. Hay (1999) went so far as to claim that schools were in 'the business of information'. Hay reported that teachers in Australasian schools had undeveloped ideas about the nature and purpose of information policy. She concluded that typically Australian schools had few information policies in place. Notwithstanding that schools are in the information business it seems that few schools are well attuned to information issues and generally have little policy developed to tackle these challenges.

According to Hay the key information policy issues affecting schools include the general areas of: acceptable use of the Internet; copyright and intellectual 
property rights; technology planning; right to privacy; and access to information versus censorship. These policy areas are discussed below with reference to Hong Kong.

\section{Acceptable use policy}

A proliferation of electronic resources, and primarily those on the Internet, has given rise to very contentious issues of access to information in an information environment that cannot rigorously regulate so called 'adult only' materials. Ostensibly, this set of policies seeks to ensure that the whole school/organisation community uses these resources responsibly and through guidelines for the appropriate use of computer networks. It is supposed to provide an answer to the concerns of all stakeholders. These guidelines are generally called an Acceptable Internet Use Policy, or AUP. Virginia Department of Education, Division of Technology has compiled a helpful handbook on AUPs. They define an AUP as a "written agreement in the form of guidelines, signed by students, their parents and their teachers, outlining the terms and conditions of Internet use-rules of online behaviour and access privileges” (Acceptable Internet Use policies, n.d.).

The Education and Manpower Bureau (EMB) of Hong Kong, which formulates, develops and review policies in respect of education from kindergarten to tertiary levels, has its own guidelines on the use of the Internet in schools. These guidelines include the security and conduct of surfing the Internet which aims to regulate the students' access to websites only of which teachers consider to be educational (EMB, 1996).

\section{Copyright and intellectual property}

This is a large area where schools must define carefully, fair use of materials. Because educators use a variety of resources in learning and teaching, legal issues abound. Public performance of media, photocopying of print items and Internet resources raise questions often not easily answered. However, the Hong Kong Government introduced the Copyright (Amendment) Bill 2003 which narrows the scope of the end-user criminal liability as a long-term measure because the public were concerned that it would seriously undermine classroom teaching and the dissemination of information (Intellectual Property Department, 2004).

Central to copyright and intellectual property issues is the challenge of plagiarism. How can educators deal with the common downfalls of the copy and paste learning now exacerbated by the Internet? A policy outlining information literacy standards could help improve forms of assessment so that plagiarism was no longer an issue. It could also assist teacher librarians through collaboration with teachers to develop information literacy skills, including teaching students lifelong skills in the ethical use of information (Information Literacy for the $21^{\text {st }}$ Century, 2004).

\section{Technology planning}

Schools have likely placed emphasis on the planning of software and hardware acquisition in facilities. This planning, embodied in policy and linked to overall technology integration and professional development, is included in information policy.

...modern computers and telecommunication networks alone will not be enough to improve learning. Educators and 
librarians must begin with a clear vision of how these tools can be linked with strong professional development strategies, new curriculum content and enhanced services to improve schools and libraries. Careful planning and sound operational strategies will ensure that school and library investments in information technology pay off in significant education and library service advancements. (Universal Service Administrative Company, Section 2.I. The Technology Plan)

According to the Quality Assurance Inspection Annual Report 2003/4 by the EMB, the library facilities and information technology infrastructures of Hong Kong schools were generally abundant. However, the EMB's findings criticised that, "half of the schools did not formulate specific goals, plans and strategies in using IT to enhance teaching and learning... resulted in fairly great disparity in effectiveness.” It appears that those schools would need to further develop on their technology planning.

\section{Privacy}

Another area where policy is well developed is privacy. School records and sensitive information are protected very clearly under Hong Kong ordinances. The Personal Data Privacy Ordinance (Chapter 486 of the Laws of Hong Kong) guides the storage and access for both student and personnel data in schools. How this set of laws and policies are communicated is an area to be studied. However, the Office of the Privacy Commissioner for Personal Data has already begun to educate the importance of protecting and respecting privacy rights to Hong Kong primary students by organizing live shows which integrates music, games and drama in April 2004 and relaunched the show in March 2005 (Office of the Privacy Commissioner for Personal Data, 2005).

\section{Access to information}

The Internet adds a new level to the intellectual freedom debate. However, even classic debates of censorship and the right to access sensitive materials in library collection need addressing. Anecdotal evidence suggests that few schools have collection development policies that outline rationale for selection or provide procedures for challenged materials. Despite being an unregulated access to information possibility by students, nevertheless, the Guidelines on Using Internet Resources in Schools (EMB, 1996) do state some rules for restricting access and usage of the Internet as means for searching information.

Moore (1997) argues that information policy is developed to a large extent, through lobbying efforts of individuals at the micro level in organizations. It is within organizations where critical issues arise that macro policy can be shaped. Educators are the best to identify, explain context and background, and communicate information policy needs to government. It is at the school or district level that information policy needs greater development. An example can be seen from Hong Kong where the EMB has attempted to raise issues with respect to information use in schools. This government department has not set policy but has guided education reform in the context of pedagogical change and in the wider context of increasing electronic information use. The report on the Hong Kong government's review of the five year 
strategy for Information Technology in education is Information Technology in Education: Way Forward outlines recommendations on the use of IT in Education with a focus on information literacy. But more recently, the Empowering Learning and Teaching with Information Technology report published in July 2004, aims to set strategic goals of enhancing school leadership and promoting community-wide support with using IT.

\section{Benchmarking policies**}

A study was conducted by the writers to benchmark policy practice in schools in Hong Kong. The purpose of this study was to develop a preliminary idea of the stage of development of information policies in Hong Kong schools and the emphasis placed on specific policies. Were policies written or unwritten? Were teachers aware of the existence of policies? Were schools applying decisions about information usage according to written statements, policies or guidelines? Which policy areas received most attention and which were largely ignored?

The study employed both quantitative and qualitative methodology. The instrument [Appendix A] was developed via the use of a Delphi process where invited experts provided input of specific policies. Consensus was reached within the project team as to which policies should be included on the questionnaire. The questionnaire thus became a checklist of policies. Respondents were requested to indicate types of policies, ranging from very formal to verbal policies. Explanatory notes for each type were included to guide respondents in choosing policy characteristics.

Demographic data was not collected but respondents were all in-service teachers in primary and secondary schools. The questionnaire was administered in a trial with students to flag any issues of clarity. It was then administered online to students in library and information studies and information technology in education programs at the University of Hong Kong.

\section{Conclusion}

This review of the literature has reinforced the claim that information policy is a topic more talked about than understood. The authors are particularly interested in understanding how information policies are debated and developed. It could be argued that schools have a particular responsibility to develop information policies because of the role of the teacher in loco parentis. Indeed there is a significant literature dealing with school and controversial information issues such as censorship, access to 'adult' material on the Internet, copyright and plagiarism. Yet it would appear from this study that information policy development in schools is a topic more understood from what has not been researched than from what has been researched. Indeed with recent attention fixed on the practices of information literacy and knowledge management it is time for greater understanding of policy issues. The small-scale project undertaken by the researchers is a preliminary step in a wider agenda to address the challenge of gaps in the research concerning information policy development in schools.

The authors wish to acknowledge the valuable feedback and assistance of Alan Chan, research assistant at the University of Hong Kong, Centre for Information Technology in Education. 
*This paper is based on a previously published article: Henri, J. \& Lee Henri Kandelaars. (2005). Information policy in Hong Kong and beyond: A review of the literature with implications for school libraries. New Review of Children's Literature and Librarianship 11(1), 63-72.

** This small scale Hong Kong-based study will form the focus of the conference presentation. The work was made possible by a grant from the University of Hong Kong, Small Project Funding and Research funds from the Centre for Information Research, the University of Hong Kong.

\section{References}

Acceptable Internet Use policies: A handbook Virginia Department of Education. (n.d.) Retrieved July 9, 2004 from http://www.pen.k12.va.us/go/VDOE/Technology/AUP/home.shtml

Bigum, C. (2004). The knowledge producing school. Retrieved November 10, 2004 from http://www.cite.hku.hk/events/doc/2004/ChrisBigumhksem/

Bishop, A. (Dec, 1993) The National Information Infrastructure: Policy Trends and Issues. ERIC Digest. (ED368324). Syracuse, NY: ERIC Clearinghouse on Information and Technology.

Braman, S. (1989). Defining information: An approach for policy makers. Telecommunication Policy, 13(3), 233-242.

Browne, M. (1997). The field of information policy: 1. Fundamental concepts. Journal of Information Science, 23(4), 261-275.

Buckland, M. K. (1991).Information as thing. Journal of the American Society for Information Science. 42(5), 351-360.

Burger, R.H. (1993). Information policy: A framework for evaluation and policy research. Norwood, NJ: Ablex.

Caldwell, B. and Spinks, J. (1988) The Self-Managing School. London: Falmer Press.

Cooper, C., \& Boyd, J. (1995). Schools as collaborative learning communities. Retrieved November 2, 2004 from http://www.vision.net.au/ globallearning/pages/lfs/clc_artcle.html

Debowski, S. (2003). In K. Dillon, J. McGregor, \& J. Henri (Eds.) (2003). Collection Management for School Libraries. Lanham, MD: Scarecrow Press.

Education and Manpower Bureau. (2005). Quality Assurance Inspection Annual Report 2003/4. p. 8. Retrieved from June 20, 2005 from http://www.emb.gov.hk/FileManager/EN/Content_756/qa_annualreport_03-04_eng.pdf

Education and Manpower Bureau. (2004). Empowering Learning and Teaching with Information Technology. Retrieved from June 20, 2005 from http://www.emb.gov.hk/index.aspx?langno=1\&nodeid=2497

Educational and Manpower Bureau. (1996). Guidelines on Using Internet Resources in Schools. Retrieved June 17, 2005 from http://www.emb.gov.hk/FileManager/EN/Content 2342/guide_ef.doc

Hay, L. (1999). Information policy issues: Curse or cure. In L. Hay \& J. Henri. (Eds.), The Net effect: School Library Media Centers and the Internet. London: Scarecrow Press, pp. 160-74l.

Henri, J. (2005). What is an information literate school community and what are the implications for teacher librarians? Retrieved January 27, 2005 from http://www.cite.hku.hk/people/jhenri/doc/InformationLiterateSchoolCommunity.pdf

Henri, J. (1999). The information literate school community: Not just a pretty face. In J. Henri \& K. Bonanno. (Eds.), The information literate school community: Best Practice. Wagga Wagga, NSW: Centre for Information Studies, pp. 1-10. 
Henri, J. (1995, August). The Information Literate School Community: Exploring a Fuzzy Concept. SCAN, 14(3), 25-28.

Home Affairs Bureau. (1999). First Report of the HKSAR of the People's Republic of China in the light of the International Covenant on Civil and Political Rights. Retrieved June 15, 2004 from http://www.hab.gov.hk/en/policy_responsibilities/the_rights_of the individuals/prc.htm

Hong Kong Policy Research Institute. (1998). A Report on a Pilot Study of the Hong Kong Information Infrastructure (Final Report). Retrieved March 26, 2004 from http://www.hkpri.org.hk/hkii/HKII\%20Report.html

Hong Kong Internet Service Providers Association. (n.d.) Development of information superhighway and Internet in Hong Kong retrieved July 9, 2004 from http://www.hkispa.org.hk/pd-970224.doc

Information Literacy for the $21^{\text {st }}$ Century. (2004). Retrieved June 20, 2005 from http://www.emb.gov.hk/FileManager/EN/Content_4424/il\%20paper(sandy)_17_2_2005_ve r2.doc

Information Technology in Education - Way Forward. (2004). Retrieved July 9, 2004 from http://www.emb.org.hk/ited/consultation_ited/eng/

Intellectual Property Department. (2004). Review of Certain Provisions of Copyright Ordinanace. Retrieved from http://www.ipd.gov.hk/eng/pub_press/consultation/Consultation_Document_eng.pdf

Levinson, B. \& Sutton, M. (2001). Introduction: Policy as/in practice: A Sociocultural Approach to the Study of Educational Policy. In M. Sutton (Ed.), Policy as practice: Toward a comparative sociocultural analysis of educational policy. (pp 1-22). Westport, CT: Greenwood.

Lincoln, P. (1987). The learning school. London: British Library.

McIntyre, B.T. (n.d.) Internet regulation in Hong Kong. Retrieved July 9, 2004 from http://www.rthk.org.hk/mediadigest/md9812/dec_3a.html

Moore, N. (1997). Neo-Liberal or Dirigiste? Policies for an Information Society. In I.

Office of the Privacy Commissioner for Personal Data. (2005). Retrieved June 22, 2005 from http://www.pco.org.hk/english/infocentre/press_20050304.html

Rowlands (Ed.), Understanding information policy: Proceedings of a workshop held at Cumberland Lodge, Windsor Great Park, 22-24 July 1996. (pp. 89-100). London: Bowker-Saur.

Overman E. \& Cahill A. (1990) Information Policy: A study of values in the policy process. Policy Studies Review. 9(4), 803-818.

Rowlands, I. (1997). Understanding information policy: Proceedings of a workshop held at Cumberland Lodge, Windsor Great Park, July, 22-24 1996. New Providence, NJ: Bowker-Saur.

Rowlands, I. \& Vogel, S. (1991). Information policie : A sourcebook. London: Taylor Graham.

Stenmark, D. (2002). Information vs. knowledge the role of Intranets in Knowledge management. Paper presented at the $35^{\text {th }}$ Annual Hawaii International Conference on System Sciences.

Universal Service Administrative Company. (2004). Technology Planning—Schools and Libraries. Retrieved November 29, 2004 from http://www.sl.universalservice.org/apply/step2.asp

Weingarten, F. (1989). Federal information policy development. In C. McClure, P. Hernon, \& H. Relyea. (Eds.) United States Government Information Policies. Norwood, NJ: Ablex.

\section{Authors note}

James Henri and Sandra Lee are academics in the Division of Information \& Technology Studies, Faculty of Education, University of Hong Kong, Hong Kong. Both teach subjects for the MSc Library and Information Studies program and the BEd Library and Information Studies program. James arrived at HKU in 2001 from Australia where he taught at Charles Sturt University. Sandra is originally from Canada and worked as a children's librarian and information specialist. 


\section{Appendix A}

The questionnaire contained a list of policies, asking respondents to indicate if they had them in place at their school. Explanatory notes were provided for written policy, written guidelines, verbal policy, no written or verbal policy or guidelines.

Please indicate if you have the following list of information policies. Indicate:

Written Policy; Written Guidelines; Verbal Policy; No written or verbal policy or guidelines or Don’t know

\section{ACCESS TO THE INTERNET}

01. General statement about Access to the Internet

02. Position statement

03. Use of Multimedia Production Centre

04. Instructional Use of Internet

05. Internet acceptable use policy

06. Internet filtering and blocking

07. Web Page Publishing Policies

\section{INTELLECTUAL PROPERTY}

08. General statement about intellectual property

09. Copyright

10. Material published by the school where I work eg. lesson plans and materials created for use at my school

11. Use of copyright protected materials created outside the school

12. Categories of material for which copyright has been waived

13. Photocopying materials created by the school

14. Photocopying materials created outside the school eg. textbooks

15. Downloading online resources

16. Using materials created outside the school in lesson planning 
17. Videos with public performance or other licensing issues

18. Using and lending CD-ROMs

COMPUTER NETWORK USAGE

19. Electronic mail (Staff use)

20. Electronic mail (Student use)

21. Electronic mail (Parents access)

22. Access to computer resources outside of regular school instructional hours

PRIVACY

23. General statement about data privacy

24. Data security on networks

25. Authorized disclosure of personal information

26. Access to personal information by students and parents eg. attendance, performance, etc.

27. Complaint procedure for parents and students

28. Privacy Coordinator

Students

29. Students' records

30. Destruction of records of deceased students

31. Referral procedures, forms

32. Photos of students

33. Enrollment data

34. Library borrowing records

35. Creating materials

36. Using photographs of students

37. Creating school web pages; guidelines for style, format and content

Teachers

38. Professional growth plan 
39. Promotional information

40. Teacher Technology Standards

41. Teaching plans

42. IT integration

43. Assessment procedures, forms

44. Competency statements

ETHICAL USE OF INFORMATION

45. Standard citation or referencing style eg. APA

46. Academic dishonesty

47. Plagiarism

48. Pirated copies of materials

SCHOOL LIBRARY RESOURCE MANAGEMENT

49. General collection development policy

50. Selection policy (Print materials)

51. Selection policy (Electronic materials)

52. Selection policy (Web sites included in school or school library web page)

53. Selection policy (Library collection selection criteria)

54. Lending policy

55. Access to the library resources

56. Request (by students, parents or staff) for reconsideration of offensive library materials

57. Statement about intellectual freedom

INFORMATION LITERACY

58. Copyright

59. Information literacy standards

60. Information literacy definition 
61. Staff development to improve information literacy skills and implement in curriculum

TECHNOLOGY PLANNING

62. Mission Statement

63. Vision Statement

64. Learning links on Web page

65. Curricular and instructional needs

66. Information infrastructure

67. Computer literacy standards for students

68. Computer literacy standards for teachers

69. Technical support

70. Hardware and software needs

71. Equipment needs

72. Licensing agreements for software

73. Knowledge management

74. School intranet

75. Evaluation of technology planning

ADMINISTRATION

76. Access to shared folders on school network

77. Description of computer files/folders

78. Document (print and electronic) management

79. Meeting minutes storage

80. Networking computers

81. Use of CCTV systems

82. Staff technology training program 
83. IT coordinator role

84. Backup procedures for data

EVALUATION OF STUDENT PROGRESS

85. Student handbook

86. Pupil profile forms

MISCELLANEOUS INFORMATION POLICES

87. Incident reporting

88. School developments involving private finance; contract management

LIST OF POLICIES MISSING

89. Please add any information policies implemented at your school and not on the above list here. 
Reproduced with permission of the copyright owner. Further reproduction prohibited without permission. 